\title{
The Writing of West European History: A Bird's-Eye View of Trends between 1960 and 1964
}

\author{
By Sylvia L. Thrupp
}

$\mathrm{O}^{\mathrm{s}}$ NLY a multilingual computer could make a statistically correct breakdown of the flood of writing on European historical questions that issues from printing presses annually. No bibliographical series pretends to cover it all, and national bibliographies lag. There are, however, better and livelier clues to the main streams of interest within Europe itself, in the published proceedings of the congresses now organized quinquennially by the International Committee of Historical Sciences. ${ }^{1}$ Americans and other non-Europeans help to prepare the congress programs, but these are predominantly European both in subject matter and in their temporal horizon. Whereas conventions of the American Historical Association convey the impression that history is a mere introduction to the present, the European congresses treat the twentieth century as a mere appendage to history.

1 For the last of these, see $\mathrm{XI}^{\mathrm{e}}$ Congrès International des Sciences Historiques, Actes $d u$ Congrès: Résumés des communications, and Rapports, Vols. 1-5 (Stockholm, 1960).
In the meetings held at Stockholm in 1960, the section on "Contemporary History" was considered to be the appropriate place for papers on the problem of nationalism in the Hapsburg Empire and on nineteenth-century business enterprise. In convivial conversation at Stockholm, one "modern" historian voiced the conviction that any history written on times later than the seventeenth century is bound to be mere political propaganda. The "contemporary" historians must have set the cooling-off span at about fifty years, for they were able to discuss German politics of the World War I era. ${ }^{2}$ Nor did the congress flinch from heated controversy over Marxist historiography. ${ }^{3}$ But head-on discussion of the World War II era was avoided. ${ }^{4}$

2 See Rapports, op. cit., Vol. 5, pp. 61-96 and Actes du Congrès, op. cit., pp. 213-220.

${ }^{3}$ Rapports, op. cit., Vol. 1, pp. 74-88 and Actes du Congrès, op. cit., pp. 56-67.

4 The program of the next congress (printed in The American Historical Review, October 1963, pp. 291-296), to be held in August 1965

Sylvia L. Thrupp, Ph.D., Ann Arbor, Michigan, the Alice Freeman Professor of History at the University of Michigan, is a medievalist who formerly taught in the Department of History of the University of British Columbia and in the Social Sciences Staff of the College of the University of Chicago. Her book publications include The Merchant Class of Medieval London (1948; Paper-bound edition 1962) and, as editor, Millennial Dreams in Action (1961) and Change in Medieval Society (1964). She is a contributor to The Cambridge Economic History of Europe, Vol. III (1963) and to other books and several journals. She is founding editor of Comparative Studies in Society and History (1958-). 
This bird's-eye report will subordinate both the question of temporal horizon and that of conventional classification by subject matter to spatial and social horizons. To what extent are historians treating Western Europe as a self-contained entity? To what extent do they work within national or regional horizons? And is there any connection between the radius of these horizons and the development of new methods?

\section{Work on West Europe as an Entity}

Rooted in the traditions of ecclesiastical history, the view of Western Europe as an entity has been progressively enriched by specialized concentration on diplomacy, law, and other institutionalized aspects of its state system, as well as on economic development, demography, intellectual movements, and art history. A reader asking for a general picture of Europe in a given period will find that almost any recent specialized work-whether the subject be heresy, ${ }^{5}$ banking, ${ }^{6}$ cultural relations between just two countries, ${ }^{7}$ or the spread of a philosophy ${ }^{8}$-will enable him to perceive some new aspect of Europe as a network of internal lines of communication or of forms of organization that intersect or influence each other. To be sure, in writing that has to concentrate on

at Vienna, will include a session on "The Impact of the German Military on the Political and Social Life of Germany during World War II."

${ }^{5}$ For example, René Nelli, Le phénomène cathare: Perspectives philosophiques, morales, et iconographiques (Paris, 1964).

B Raymond de Roover, The Rise and Decline of the Medici Bank, 1397-1494 (Cambridge, Mass.: Harvard University Press, 1963); Olle Gasslander, History of Stockholms Enskilda Bank to 1914 (Stockholm, 1962).

7 J. S. Bromley and E. H. Kossmann (eds.), Britain and the Netherlands (2 vols.; Gronigen, 1960,1964 ).

8 W. M. Simon, European Positivism in the Nineteenth Century: An Essay in Intellectual History (Ithaca, N.Y.: Cornell University Press, 1963). some short-lived stream of events, these structural outlines tend to be submerged. The art, and the supreme difficulty, of longer-run historical writing lies in keeping an equally firm hold on events and on structural change, and in doing so without distorting people's motivation. Formerly these criteria were little used except for singling out giants - the great historians. Otherwise, failure to weave structural change into a narrative was matter for reproach only among constitutional and legal historians. Today, men once regarded as great historians are professionally disregarded. Kitson Clark's recent remarks on G. M. Trevelyan show how professional judgment diverges from that of the popular reading public: "Like all his contemporaries, he was accustomed to make the sort of generalization about social conditions and attitudes which scholars found increasingly difficult to accept." 9 In other words, structural change was once handled by guesswork, but is now a matter of serious study by means of new techniques, including, as Dr. Clark emphasizes, statistical techniques. The standards which the ordinary historian is expected to meet are steadily rising. Anyone may now be reproved for neglecting to weave structural elements into his narrative. A severe example is the criticism leveled by a French reviewer in 1962 against a recent American work on the Crusades, to the effect that some of it gave an impression of confusion by separating the history of events from that of structural change..$^{10}$

Among the forms of structuring to which European historians have given great attention are those of representative institutions and bureaucracies. Two recent Festschrift volumes honor-

${ }^{9}$ G. Kitson Clark, "G. M. Trevelyan as an Historian," Durham University Journal, LV (1962), pp. 1-4.

10 See Revue historique, Vol. 232 (1964), p. 220. 
ing Helen Cam's service to the International Commission for the History of Representative and Parliamentary Institutions contain thirty-five essays in five languages, their subjects ranging from change in Lombard assemblies in the eighth century to the role of the Norwegian Storting in the 1905 movement for independence. ${ }^{11}$ Dietrich Gerhard is the leading exponent of more explicitly comparative work setting the bureaucracies of the seventeenth and eighteenth centuries in the full social and political context of "estate society." 12 The publications of the Société Jean Bodin, resulting from conferences held usually on some aspect of legal institutions, continue to apply some comparative analysis throughout Europe and beyond it. ${ }^{13}$

European standards in what Americans style "intellectual history" tend to be higher in that, instead of stopping short with the exposition of ideas and showing their inner development, historians go on to careful study of the channels of communication through which they are diffused. ${ }^{14}$ At its best, as in Franco Venturi's superb paper on Illuminismo in the seventeenth century, this type of writing truly displays West

11 Album Helen Maud Cam, Vols. XXIII and XXIV, in Studies Presented to the International Commission for the History of Representative and Parliamentary Institutions (Louvain and Paris, 1960-1961).

${ }^{12}$ See his "Amtsträger zwischen Krongewalt und Ständen-ein europäisches Problem," in Alteuropa und die moderne Gesellschaft: Festschrift für Otto Brunner (Göttingen, 1963), pp. 230-247, and his "Regionalismus und ständischen Wesen als ein Grundthema europäisches Geschichte," in Alte und neue Welt in vergleichender Geschichtsbetrachtung (Veröffentlichungen des Max-Planck-Instituts für Geschichte, No. 10; Göttingen, 1962), pp. 13-39.

${ }^{13}$ See especially La Paix, Recueils de la Société Jean Bodin, Vols. XIV, XV (Brussels, 1961-1962).

14 See Daniel Roche, "La diffusion des lumières," Annales: Economies, Sociétés, Civilisations, $19^{\circ}$ année, No. 5 (1964), pp. 887-922.
Europe as a living entity. ${ }^{15}$ The proceedings of the conference on scientific change which A. R. Crombie organized at Oxford to bring the small and scattered band of historians of science into closer touch make fascinating reading both in the evolution of ideas and in history of the means by which new advances were communicated. ${ }^{16}$ The volume reproduces the formal papers that were presented, as well as a verbatim report of the argument to which they gave rise.

Spirited argument enlivens also the published proceedings of the conferences. which specialists in the early middle ages hold periodically at Spoleto. Each conference explores one set of problems -ecclesiastical, political, or economicthroughout the whole of Europe, with emphasis upon the West. A leading scholar then sums up the general conclusions to be drawn from the new research presented and the criticism to which it has been subjected. ${ }^{17}$ Thanks in part to the Spoleto stimulus, research in this exceedingly difficult period is making faster headway. To mention only one recent book, Pierre Riché's account of schooling between the sixth and eighth centuries should be on every reading list in the history of Western education. ${ }^{18}$

Although discretion has hitherto barred recent political history from scholarly conferences in Europe, Europeans certainly do not refrain from writing it, and Americans are more drawn to this field of European history than any other. How great a struggle it is to turn the

${ }^{15}$ Rapports (XI $\mathrm{X}^{\mathrm{e}}$ Congrès), op. cit., Vol. IV, pp. 106-135.

${ }^{16}$ A. R. Crombie (ed.), Scientific Change (London, 1963).

${ }_{17}$ Moneta e Scambi nell'alto Medioevo, Settimane di Studio del Centro Italiano di Studi sull'alto Medioevo, Vol. VIII (Spoleto, 1961).

${ }^{18}$ Pierre Riché, Education et culture dans loccident barbare: VIe-VIIIe siècles, Patristica. Sorboniensia, No. 4 (Paris, 1962). 
cold objective light of power politics onto catastrophic events through which one has lived is best seen in the mixed reception of A. J. P. Taylor's The Origins of the Second World War. ${ }^{19}$ F. W. Deakins, another Oxford historian, has written a dramatic and massively documented chronicle of Italy's part in the war. ${ }^{.0}$ George L. Mosse's new book on Naziism ${ }^{21}$ struggles with a problem that is recurrent in the history of millennialism: How is one to detect and explain the point at which the elements of an ideology, long afloat separately, merge into a complex which suddenly acquires power? American readers will find a reliable guide to the fast-growing body of work on Europe's twentieth-century ordeal in the review pages of The Journal of Modern History, which cover contributions in all languages.

Economic history has displayed amazing vitality by inaugurating independent international meetings of its own for exchange of ideas bearing not only on Europe but on economic development throughout the world. ${ }^{22}$ It tends, in Europe as elsewhere, towards increasing use of theory and of statistical techniques as an aid to comparative study. It tends in Europe, perhaps more than elsewhere, to lay increasing stress on demography and on agrarian history. A little unsettling to older historians un-

${ }^{19}$ First issued in 1961, but see his revised introduction to the second edition, explaining and defending his position (London, 1963).

${ }^{20} \mathrm{~F}$. W. Deakins, The Brutal Friendship: Mussolini, Hitler and the Fall of Fascism (New York, 1962). Documented from German and Italian archives.

21 George L. Mosse, The Crisis of German Ideology: Intellectual Origins of the Third Reich (New York, Grosset and Dunlap, 1964).

22 First International Conference of Economic History: Contributions (Paris, 1960). Proceedings of the second conference have yet to appear. A third conference will meet at Munich in August 1965. In addition there are always sessions on economic history at the main international historical meetings. accustomed to think in ratios, it is at the same time a unifying influence in European historical study because its problems in all periods cut across national frontiers. To take examples from agrarian history: Folke Dovring's Land and Labor in Europe, 1900-1950 ${ }^{23}$ unifies twentieth-century study, and Georges Duby has done the same for the problems of medieval agrarian life in different regions and countries. ${ }^{24}$ Further, a new French journal is exploring a variety of ways of studying peasant life in all periods and areas. ${ }^{25}$ To counteract this tendency to split into subspecialties, economic history has to attempt synthesis. The Cambridge Economic History of Europe has put out two volumes in the last five years, ${ }^{26}$ has two earlier volumes now out of print under revision, and further volumes in press. Each is a series of chapters by different authors who occasionally overlap and disagree. Slighter but highly suggestive volumes, by single authors, are coming out in Paris more quickly, in the Nouvelle Clio series. ${ }^{27}$

Another type of partial synthesis attempted within the West European horizon is in religious history. Research in this is so voluminous and so diversified that fairly full general surveys are periodically a necessity. A brilliant work by Gabriel Le Bras, the latest addition to a continuing French series in

${ }^{23}$ With a chapter on "Land Reform as a Propaganda Theme," by Karin Dovring. (2d ed.; The Hague, 1960). A third edition is in press.

${ }^{24}$ Georges Duby, L'economie rurale et la vie des campagnes dans l'Occident médiéval (2 vols.; Paris, 1962).

${ }^{25}$ Etudes Rurales, ed. Isac Chiva (Paris).

${ }^{26}$ Cambridge Economic History of Europe, Vol. III, Economic Organization and Policies in the Middle Ages (New York: Cambridge University Press, 1963) and Vol. VI, The Industrial Revolution and After (New York: Cambridge University Press, 1964).

${ }^{27}$ See Jacques Heers, L'Occident aux XIVe et XVe siècles (Paris, 1963). 
ecclesiastical history, describes the development of the medieval church as an organization, from the point of view of religious sociology. ${ }^{28}$ Three other highly original French books have used the strategy of vertical synthesis of a variety of scattered evidence, through time, to open up subjects which historians have touched on only incidentally-work, ${ }^{29}$ childhood, ${ }^{30}$ and insanity. ${ }^{31}$ Like the first of these, L'histoire de travail, Lewis Mumford's The City in History ${ }^{32}$ ranges beyond Europe but deals substantially with Europe and is beautifully illustrated; it is also a passionate book. In the political dimension, Adam Wandruszka's history of the Hapsburg dynasty takes a deep vertical cut. ${ }^{33}$

There is more activity in general writing on the nineteenth and twentieth centuries. Little of this takes much note of the character or role of cities: as D. W. Brogan has deplored, there is a lack of basic research in this field. ${ }^{34}$ The new books continue to be preoccupied with re-examining old interpretations that were either primarily economic or primarily political. For the so-called revolutionary age, from 1789 to 1848 , E. J.

${ }^{28}$ Gabriel Le Bras, Institutions ecclésiastiques de la chrétienté médiévale, Histoire de l'Eglise, ed. J. B. Duroselle and Eugène Jarry, No. 12, Part I, Books 2-6 (Paris, 1964). Book 1 appeared in 1959.

${ }^{29}$ Philippe Wolff, Histoire générale du travail (Paris, 1959-1961).

30 Philippe Ariès, Centuries of Childhood (London, 1962), translated from the first French edition (Paris, 1960).

31 Michel Foucault, Histoire de la folie (Paris, 1961).

32 Lewis Mumford, The City in History: Its Origins, Its Transformations, and Its Prospects (New York: Harcourt, Brace and World, 1961).

${ }^{33}$ Adam Wandruszka, The House of Habsburg: Six Hundred Years of an European Dynasty (New York, 1964).

${ }^{34} \mathrm{D}$. W. Brogan, in John Burchard and Oscar Handlin (eds.), The Historian and the City (Cambridge, Mass.: Harvard University Press, 1963), pp. 146-164.
Hobsbawm develops a compromise solution in an interesting manner, with stress on the cultural changes which require to be explained..$^{35}$

\section{West Europe in Wider Context}

In political history, and in diplomatic and economic research, there is a long tradition of trying to keep the whole of Europe in a common perspective, as well as of tracing its "expansion." Scandinavian studies of Viking enterprise and influence reach into the Middle East, ${ }^{36}$ and Byzantine and Islamic studies are more lively than ever before. Norman Daniel $^{37}$ and James Kritzeck ${ }^{38}$ are studying Moslem-Christian cultural relations in novel ways. The new Journal of the Economic and Social History of the Orient ${ }^{39}$ is constantly breaking new ground, with results relevant to European history. Robert Lopez, the great Mediterranean medievalist of Yale University, has rewritten the story of the "birth" of Europe as an entity for a French series on "World Destinies," magnificently illustrated. ${ }^{40}$ Donald Lach, of the University of Chicago, following the fascinating trail of early travel literature and maps, has just published the first two parts of a multivolume work on Asia's cultural influence on Europe throughout the centuries. ${ }^{41}$

35 E. J. Hobsbawm, The Age of Revolution: Europe from 1789 to 1848 (London, Cleveland: World, 1962).

${ }^{36}$ For a summary of their scope see Sture Bolin's address in the Actes of the Eleventh International Congress of Historical Sciences, pp. 19-25.

37 Norman Daniel, Islam and the West: The Making of an Image (Edinburgh, 1960).

38 James Kritzeck, Peter the Venerable and Islam (Princeton, N.J.: Princeton University Press, 1964).

39 Journal of Economic and Social History of the Orient (Leiden, 1959).

${ }^{40}$ Robert Lopez, La naissance de l'Europe (Paris, 1963).

41 Donald F. Lach, Asia in the Making of Europe (Chicago: University of Chicago Press, 1964). 
Greater depth of understanding of the cultural influence on Europe itself, of the process of "expansion," together with belated realization of the fact that Western imperialism is only a part of the history even of Africa, ${ }^{42}$ is revolutionizing the history of European expansion. Frédéric Mauro has surveyed it afresh, from the vantage point of profound research in Spanish and Portuguese enterprise, in the adventurous Nouvelle Clio series. ${ }^{43}$ The late Richard Koebner's work on the forms that the idea of Empire has taken has been brought up to date. ${ }^{44}$ Cambridge has entirely abandoned the point of view of the old Cambridge Modern History, written in the early years of this century as a kind of encyclopedia of the international relations of European states. The editors of The New Cambridge Modern History feel that synthesis is nowadays best attempted through suggestive essays indicating the present state of research on major problems, essays that may be read with pleasure. ${ }^{45}$

There is another old tradition, primarily German and French, of writing

42 See D. A. Low's review article, "Studying the Transformation of Africa," Comparative Studies in Society and History, VII (October 1964), pp. 21-36.

${ }^{43}$ Frédéric Mauro, L'expansion européenne, 1600-1870 (Paris, 1964).

${ }^{44}$ Richard Koebner, Empire (New York: Cambridge University Press, 1961); and Richard Koebner and H. D. Schmidt, Imperialism: The Story and Significance of a Political Word (New York: Cambridge University Press, 1964).

${ }^{45}$ The New Cambridge Modern History, Vol. X, ed. S. P. T. Bury: The Zenith of European Power, 1830-70 (New York: Cambridge University Press, 1960); Vol. XII, ed. D. Thomson: The Era of Violence, 1898-1945 (New York: Cambridge University Press, 1960) ; Vol. V, ed. F. L. Carsten: The Ascendancy of France, 1648-88 (New York: Cambridge University Press, 1961); Vol. XI, ed. F. H. Hinsley: Material Progress and WorldWide Problems, 1870-1898 (New York: Cambridge University Press, 1962). encyclopedic world histories in which sections or volumes on European history are sandwiched between studies of other civilizations, leaving the reader to digest the whole as best he can. William McNeill has now resumed the Spengler-Toynbee variant of this tradition, through Herculean labor compressing the history of "the human community" into a single volume. ${ }^{46}$ His philosophy differs from Spengler's and Toynbee's vision of separate civilizations endowed with separate "spirits," owing more to the late A. L. Kroeber's emphasis on the flow of cultural interchange as a continuing process since the dawn of civilization. McNeill has mapped, through space and time, the movements of people, gods, technology, ideas. He has not tried to satisfy the requirements of any branch of the social sciences, but simply to widen the horizon within which comparative study must get to work. The very simplicity of his approach is morally impressive.

\section{National Histories}

The majority of historians, in Europe as in America, continue, nevertheless, to work within national horizons. On Belgian history alone, 1961 saw the publication of 1400 books and articles. Most of such work remains within the conservative traditions in which students are trained, and only a few trends that are fresher can be noticed here. In England it is hard to distinguish much that is fresh, beyond some interest in the use of statistical techniques. The new Oxford histories of England, proceeding century by century, give no new lead because they merely summarize recent scholarship. Political, constitutional, and administrative reinterpretations continue; Henry Pelling has

\footnotetext{
46 William H. McNeill, The Rise of the West (Chicago: University of Chicago Press, 1963).
} 
brought the history of trade unionism up to date. ${ }^{47}$ One of the few pieces of pioneering work is Richard Glover's study of the renewal of British military power in the Napoleonic era. ${ }^{48}$ Its thoroughness, its attention to the detail of arms, organization, and logistics, makes all older military history look amateurish. Another is Lawrence Stone's on the aristocracy of the late Tudor and Stuart periods. ${ }^{49}$ At Dublin, work on Irish history makes steady if conservative progress; Scandinavian work is fresher ${ }^{50}$ but all new work on the smaller countries is a welcome counterweight to the tradition of concentration on the Great Powers. In Italy, unification remains the great theme; an American work on this has been honored as the best recent book. ${ }^{51}$ In France, the Revolution of 1789 is still a central focus. Georges Lefebvre's great work on it is now translated $;{ }^{52}$ Alfred Cobban stresses the continuity and growth of French bureaucracy, in a two-volume history of modern France; ${ }^{53}$ and Jacques Godechot has re-

${ }^{47}$ Henry Pelling, A History of British Trade Unionism (New York: Oxford University Press, 1963). For an interesting discussion of recent work see John Clive, "British History, 1870-1914, Reconsidered: Recent Trends in the Historiography of the Period," American Historical Review, LXVII (1963), pp. 9871009.

48 Richard Glover, Peninsular Preparation: The Reform of the British Army, 1795-1809 (New York: Cambridge University Press, 1964).

49 Lawrence Stone, The Crisis of the Aristocracy, 1558-1641 (New York: Oxford University Press, 1964).

${ }^{50}$ Stein Rokkan, in Cleavages, Ideologies and Party System: Contributions to Political Sociology, ed. E. Allardt and Y. Littunen (Helsinki, 1964), pp. 5-18, 162-238.

${ }^{51}$ Raymond Grew, A Sterner Plan for Unity (Princeton, N.J.: Princeton University Press, 1963).

${ }^{52}$ Georges Lefebvre, The French Revolution from Its Origins to 1793 (New York: Columbia University Press, 1962).

${ }^{53}$ Alfred Cobban, A History of Modern France, (2 vols.; London, 1963). studied revolutionary thought. ${ }^{54}$ Selection, in view of the excellence of French historical scholarship, is invidious, but a foremost place must be given to the growing influence of the school of thought founded by Marc Bloch and Lucien Febvre, propagated under Fernand Braudel's guidance in the pioneering critical journal which they founded, now entitled Annales: Economies, Sociétés, Civilisations, and manifest in Robert Mandrou's attempt to interpret the early modern centuries through the dimensions of a kind of historical social psychology. ${ }^{55}$ In Germany, agrarian history is receiving new attention, ${ }^{56}$ and an American has chosen Germany as the setting for a new kind of work, on the effects, on the home country, of the great European migrations abroad. ${ }^{57}$

Much of what bibliographers classify as national history is regional or more narrowly local. Once the province of amateurs, these branches of history are in Europe now almost wholly professionalized. The process of going to the grass roots, although historians of politics and of ideas have looked down on it as a petty narrowing of horizons, has in fact frequently had the opposite effect. While the political historians' awareness of theory as an aid to the ordering of research and its findings has been limited to the older traditions of political science, historians working on local and regional sources are at some point driven

54 Jacques Godechot, La pensée révolutionnaire (Paris, 1964).

${ }_{55}$ Robert Mandrou, Introduction à la France moderne: Essai de psychologie historique, 1500-1640 (Paris, 1961), and De la culture populaire aux 17e et 18e siècles (Paris, 1964).

${ }^{56}$ See Günther Franz, Geschichte der deutschen Agrarverfassung vom frühen Mittelalter bis zum 19 Jahrhundert (Stuttgart, 1963) and the Zeitschrift für Agrargeschichte und Agrarsoziologie, edited by Günther Franz, and now twelve years old.

57 Mack Walker, Germany and the Emigration, 1816-1885 (Cambridge, Mass.: Harvard University Press, 1964). 
into awareness of the younger social sciences. This widening of theoretical horizons is most conspicuous in French and Scandinavian work. In France, it has a special impetus through training in human geography, which sensitizes historians to the idea of structure conceived as a discernible constancy of pattern in distribution maps. Pierre Goubert's masterly study of the region of Beauvais in early modern times is only one among many remarkable French studies which are both history and descriptive sociology; it stands out through the admirable documentation of its demographic chapters, based on reconstitution of families. ${ }^{58}$ Pierre Vilar's history of the Catalan region is another extraordinarily vivid study, covering a much longer time span. ${ }^{59}$ Space forbids reference to other illuminating work in German and Italian regional history. American readers may however take pride in Charles Tilly's book on the French Revolution as it was experienced in the region of the Vendée. ${ }^{60}$ Grounded in meticulous research, the book is at the same time delightfully written. It is the best demonstration to date of the value to a historian of some specific training in sociological theory. Yet Tilly ends by teasing the sociologists on what they themselves lose through the self-imposed limitations of their temporal horizon.

\section{The Significance of Current Trends}

The significance of the trends so briefly illustrated here would emerge more clearly if there were space to comment at length on current European

${ }^{58}$ Pierre Goubert, Beauvais et le Beauvaisis de 1600 à 1730 (Paris, 1960).

58 Pierre Vilar, La Catalogne dans l'Espagne moderne (3 vols.; Paris, 1962).

${ }^{60}$ Charles Tilly, The Vendée: A Sociological Analysis of the Counterrevolution of 1793 (Cambridge, Mass.: Harvard University Press, 1964). discussion of historical method in the broader sense. In Europe, philosophers of history do not merely gloss what other philosophers have said about history; they read the work of historians, creating some common discourse. Examples will be found in the writing of E. Callot, ${ }^{61}$ in the pages of the German journal Saeculum, ${ }^{62}$ and are becoming more frequent in History and Theory. ${ }^{63}$ Such discourse serves to clarify the historian's role in helping to sustain the evolution of self-consciousness. J. H. Hexter's pleasant ridicule of semantic confusions in the writing of English history is a step in this direction. ${ }^{64}$ More positive contributions will be found in a thoughtful essay of Folk Dovring's, ${ }^{65}$ in the pages of Past and Present, ${ }^{66}$ and in the collection now published of Marc Bloch's scattered articles and critical work. ${ }^{67}$ In his advocacy and practice of comparative study in history Marc Bloch made no fetish of it. If it is gaining ground today, it is not as an end in itself but as a means of helping the historian constantly to reorder his thinking to the end of keeping control of the growth of knowledge through specialization. To decry specialization is mere anemic pessimism: the record of European historiography demonstrates that we are learning, not more about less, but more about man.

${ }^{61} \mathrm{E}$. Callot, Ambiguities et antinomies de l'histoire (Paris, 1962).

${ }^{62}$ Saeculum (Frieburg im Breisgau), now fifteen years old.

${ }^{63}$ History and Theory (The Hague), three years old.

${ }^{64} \mathrm{~J}$. H. Hexter, Reappraisals in History (Evanston, Ill.: Northwestern University Press, 1961).

${ }^{65}$ Folke Dovring, History as a Social Science: An Essay on the Nature and Purpose of Historical Studies (The Hague, 1960).

${ }^{66}$ Past and Present (Corpus Christi College, Oxford).

${ }^{67}$ Mélanges historiques (2 vols.; Paris, 1963). 